\title{
A study on fragrance, aroma and emotion
}

\author{
SHIVANI SRIVASTAVA AND SANGITA SRIVASTAVA
}

Received: 04.05.2016; Accepted: 25.05.2016

See end of the paper for authors' affiliations SHIVANI SRIVASTAVA

Department of Home Science, University of Allahabad, ALLAHABAD (U.P.) INDIA

Email : shivanisrivastava25@gmail. com
ABSTRACT : Inhaling a pleasant aroma can be a very pleasurable experience and pleasant fragrances can improve our mood and sense of well being. Smell can evoke strong emotional responses and when we like or dislike any smell that is completely based on emotional connections. Under the present study a review on relationship of aroma to emotional and physical health was collected and this review article covers the areas of importance of aroma, role of aroma in various areas, relationship of aroma to emotional and physical health and aromatherapy and textile.

KEY WORDS: Aromatherapy, Essential oil, Olfaction

- HOW TO CITE THIS PAPER : Srivastava, Shivani and Srivastava, Sangita (2016). A study on fragrance, aroma and emotion. Asian J. Home Sci., 11 (1) : 252-256, DOI: 10.15740/HAS/AJHS/11.1/252-256. 